\title{
Perspectives on the Potential of Silvopastoral Systems
}

\section{Devendra*}

Consulting Tropical Animal Production Systems Specialist, 130A Jalan Awan Jawa, Kuala Lumpur, Malaysia

\begin{abstract}
The importance of animal agriculture on productivity enhancement, nutritional and food security for economic rural growth in Asia is discussed in the context of the biophysical environment, available natural resources, preponderance of small farm systems, and opportunities for increasing the potential contribution. Arable land is a critical limiting factor, and an alternative to consider are the rainfed areas. The rainfed humid/sub-humid areas found mainly in South East Asia (99 million ha), and arid/semi-arid tropical systems found in South Asia (116 million ha) are priority agro-ecological zones (AEZs). They have been widely referred to as the less favored areas (LFAs), and low or high potential. The LFAs are characterised by very variable biophysical elements, notably poor soil quality, rainfall, length of growing season and dry periods, extreme poverty, and very poor people who continuously face hunger and vulnerability. There also exist large populations of ruminant animals, notably goats and sheep. About $43-88 \%$ of the total human population depends on agriculture for their livelihoods, of which $12-93 \%$ live in rainfed areas and $26-84 \%$ on arable land. In India for example, the ecosystem occupies $68 \%$ of the total cultivated area and supports $40 \%$ of the human and $65 \%$ of the livestock populations. Revitalised development of the LFAs is justified by the demand for agricultural land to meet human needs e.g. housing, recreation and industrialization; use of arable land to expand crop production to ceiling levels; very high animal densities. Animals play a multifunctional role and more importantly they can serve as the entry point for the development of LFAs. Efficient production systems are important and silvopastoral systems are underestimated and also underutilized throughout the developing countries, and especially where tree plantations are abundant such as with oil palm in Indonesia, Malaysia and Colombia. Concreted development attention together with research and development is necessary to promote its many economic advantages e.g. total factor productivity per unit land or labour, and value addition. Additionally, the system also promotes stratification, which provides an important opportunity to intensify NRM The strategies for promoting productivity growth will require concerted $R$ and $D$ on improved use of LFAs, application of systems perspectives for technology delivery, increased investments, a policy framework and improved farmer-researcher-extension linkages. These challenges and their resolution in rainfed areas can forcefully impact on increased productivity, improved livelihoods and human welfare, and environmental sustainability in the future.
\end{abstract}

Keywords: Animal agriculture; Diversification; Food security; Feed resources; Technology application; Systems perspectives; Farming systems research; Sustainability; Integration; Strategy; Impacts; Investments

\section{Introduction}

An assessment of the pathways of prevailing food systems, and investigations to ways of increasing current supplies of food production are compelling challenges of our times. The challenges are directly associated with a number of serious concerns which include: waning agricultural growth and reduced investments in research and development $(\mathrm{R}$ and $\mathrm{D})$; rapid demographic pressures and urban migration; social pressures and consequences; increasing prices of household needs and services; social unrest and civil disorder; deprivation, survival and vulnerability; globalization and reduced capacity of small farm systems to maximize production, climate change, and stress on natural resources (land, crops, animals and water).

Asian farming systems, with their wide diversity of crops and animals, traditional methods, multiple crop-animal-environment interactions and numerous problems of farmers present increasingly complex issues associated with natural resource management (NRM) and the environment. The numerous interactions, and emerging complex constraints, underline the fact that these issues can only be fully resolved-not by any one discipline, but by communitybased participation and interdisciplinary $\mathrm{R}$ and $\mathrm{D}$, which will enable improved understanding. Education and training is a powerful and important driver of community-based participation which can sustain food security, poverty reduction and social equity.
In this context the empowerment of women in activities that support self-reliance can also be significant in increased contribution from agriculture.

Food systems are currently the defining and serious future concerns, rising incomes which are exerting tremendous pressure on the natural resources, and the capacity of science and technology to address these issues. The terms Food Security and Food Insecurity have now come to be used more widely, together with their links to poverty. Most governments see the need for a strong policy framework to support maximum food production to the extent possible, and can respond to changing consumer preferences.

A previous article published in the same journal Agro technology, a very high quality publication by OMICS, the focus of the discussion. That article emphasized the huge opportunities for improved $\mathrm{R}$ and $\mathrm{D}$, implications for land-crops-animal interactions and intensification,

${ }^{*}$ Corresponding author: Dr. C. Devendra, PhD, DSc (Nott. UK) was honoured with the Third International Animal Agriculture award at the Eleventh World Association for Animal Production Conference held in Beijing, China on $15^{\text {th }}$ October 2013 OMICS Publishing Group and the Editors congratulates him on this outstanding recognition, E-mail: cdev@pc.jaring.my

Received November 21, 2013; Accepted January 25, 2014; Published January 28, 2014

Citation: Devendra C (2014) Perspectives on the Potential of Silvopastoral Systems. Agrotechnol 3: 117. doi:10.4172/2168-9881.1000117

Copyright: (c 2014 Devendra C. This is an open-access article distributed unde the terms of the Creative Commons Attribution License, which permits unrestricted use, distribution, and reproduction in any medium, provided the original author and source are credited. 
yield-enhancing increased productivity, impacts and environmental integrity.

The intent in this article is to complement the earlier article [1] by focusing specifically on the relevance of tree crops, and the development of integrate systems with ruminants and land use. As climate change takes effect, the land available for crop production contracts and this will place much stress on food production systems. The decreased availability of arable land in the future can increase the vulnerability of the poor who live by the land, which is of great concern and likely to be a major issue for discussion. Of equal concern is the loss of about 5.7 million hectares of arable land annually through soil degradation, and a further 1.5 million hectares as a result of water logging, salinisation and alkanisation [2].

\section{Alternative options for food production: Development of rainfed areas to expand land use}

Expanding the land area to lands outside of the irrigated areas is an important option for increasing food production in the future. This is especially justified by the following reasons:-

- Increasing demand for agricultural land to meet human needs e.g. housing, recreation an industrialisation

- Expansion of crop production to ceiling levels

- Increasing and very high animal densities

- Increased resettlement schemes and use of arable land

- Growing environmental concerns due to very intensive crop production e.g. acidification and salinisation with rice cultivation

- Human health risks due to expanding and often very intensive peri- urban poultry and pig production

- Land fragmentation

- Use of arable land by expanding perennial tree crops areas, and

- Urbanization.

By definition, rainfed areas refer to all those lands outside of the irrigated, more favored or high or low potential areas. They have been variously referred to as fragile, marginal, and dry, waste, problem, and threatened, range, less favored, low potential lands, forests and woodlands, and include a reference to lowlands and uplands. Of these terms, less favored areas (LFAs), low or high potential are quite widely used and is also been used in this paper.

\section{Potential for food production systems}

Mention must be made and to draw attention to the lands immediately outside of the irrigated areas, Due to their proximity and the benefit of residual soil moisture from the irrigated areas, these same areas are designated high potential areas, primarily very valuable for crop cultivation, and now also extensively used for cultivating tree crops like coconuts, citrus, coffee, cocoa, oil palm and rubber. In Malaysia for example, over $90 \%$ of the land area is used by oil palm, rubber and cocoa.

Despite these perceptions and concerns, the tide is changing In Sabah and Sarawak, more than Peninsular Malaysia. A number of plantations have already embarked on integration with consistently demonstrable economic benefits. One very large oil palm estate not only benefits from increased yield of fresh fruit bunches (FFB), but also breeds and supplies excellent good quality Brahman cattle. The increasing interest in integrated systems in Sabah and Sarawak augers well for the future to benefit from efficiency in NRM and environmental sustainability.

Among these, the oil palm is a particularly important 'golden crop' and Asia has about $84 \%$ of the total world land area under oil palm of about 10.6 million ha. The largest land areas of 8.4 million ha of oil palm are found in Malaysia and Indonesia, who together own over $79 \%$ of the world planted area, and produce about $87 \%$ of the total world output of palm oil, followed by much smaller areas being found in Thailand, Philippines, India and Papua New Guinea. The integration model with oil palm offers extension of the principles of integration involved with other tree crops like coconuts in the Philippines, Sri Lanka and South Asia, rubber in Indonesia, and citrus in Thailand and Vietnam.

The use and development of the areas under different types of tree crops in integrated tree crop-ruminant or silvopastoral systems is grossly underestimated despite their potential very importance for several reasons. Integrated systems link the natural resources; crops, animals, land and water to economic, social and ecological perspectives. The process is holistic, dynamic, interactive, and multidisciplinary. The relevance of these systems, potential economic value, and opportunities for urgent development attention are highlighted in this paper.

\section{Extent of rainfed areas}

Table 1 provides data by region globally, on the extent and distribution of the different categories of rainfed areas [3]. In South East Asia, the total rainfed area is 99 million ha and in South Asia 116 million ha.

Table 1 also gives data on the extent of rain fed areas in individual countries. In South East Asia. the rain fed area as a proportion of total land available ranges from $63 \%$ in Indonesia. $68.5 \%$ in Malaysia to $97 \%$ in Cambodia. In South Asia, the corresponding values are from $27 \%$ in Pakistan to $84 \%$ in Nepal. Only in Pakistan and Sri Lanka does the percentage of irrigated land exceed that of the rain fed area. In absolute terms however, the largest irrigated land area of 43.8 million ha is found in India.

\section{Silvopastoral Systems}

The process of integration involving trees and ruminants is very complex due to the many variable biophysical factors and the natural production resources. Several terms have been used, but concerning the integration with ruminants [4] within which the term silvopastoral systems is being increasingly recognised:-

- Agro-forestry: involves the use of various tree crop options, usually woody perennials very commonly in rainfed areas

Table 1: Distribution of land types by region [6]

\begin{tabular}{|l|c|c|c|c|c|}
\hline \multicolumn{5}{|c|}{ Land type (\% of total land) } \\
\hline Region & Favored & Marginal & $\begin{array}{c}\text { Sparsely } \\
\text { arid lands } \\
\text { populated }\end{array}$ & $\begin{array}{c}\text { Forest and } \\
\text { wood lands }\end{array}$ & $\begin{array}{c}\text { Rural population } \\
\text { living in favored } \\
\text { lands (\%) }\end{array}$ \\
\hline Asia & 16.6 & 30.0 & 18.5 & 34.6 & 37.0 \\
\hline $\begin{array}{l}\text { Latin America } \\
\text { and Caribbean }\end{array}$ & 9.6 & 20.3 & 8.1 & 61.9 & 34.0 \\
\hline $\begin{array}{l}\text { Sub-Saharan } \\
\text { Africa }\end{array}$ & 8.5 & 23.1 & 24.6 & 43.7 & 27.0 \\
\hline $\begin{array}{l}\text { Near East and } \\
\text { N. America }\end{array}$ & 7.8 & 22.6 & 65.8 & 3.9 & 24.0 \\
\hline $\begin{array}{l}\text { Total (105 } \\
\text { countries) }\end{array}$ & 10.7 & 24.0 & 25.9 & 39.4 & 35.0 \\
\hline
\end{tabular}


Table 1: Distribution of land types by region

- Silvopastoral systems: involves trees (e.g. coconuts, oil palm and rubber) and animals

- Agro-pastoral systems: integrates crops, animals and trees.

There is a school of thought that believes that agro-forestry with its emphasis on tree crop options is a very good strategy to cope with climate change. The belief is reinforced by the view that the International Panel for Climate Change [5] have indicated that agro forestry is involved with plant biodiversity, plant species, permanent soil cover, seeds and diversification, which together with other economic, environmental and socioeconomic benefits for poor farmers and their livelihoods. The benefits are consistent with the finding earlier by CGIAR/TAC [6] that in a review of agro -forestry practices in 21 projects, $75 \%$ had net present value. In Indonesia, a case in point is growing the leguminous tree turi (Sesbania gandiflora) very commonly in the rice bunds. The legume increases soil fertility, provides fodder for animals which needs to be harvested for animals, and also young shoots and leaves for human consumption.

Silvopastoral systems by comparison are directly involved with the parent tree crop. In the case of oil palm for example, the whole system is a self-contained unit, going from breeding animals, beef production from either gazing or in situ feeding on oil palm by-products, and sale of beef for urban markets. In addition, grazing enables control of surplus grass and weeds with attendant savings in the cost of weedicides and fertilizers. More importantly, several studies have shown value addition in the output of FFB and therefore palm oil [7]. The net result is clear economic benefits, increased additional income over and above the wages from the plantations, food security; sustainable agriculture and environmental integrity. Under the circumstances, it is hard to ignore silvopasroral systems with all its challenges.

\section{Types of interactions and benefits}

There are many benefits of crop-animal-soil interactions [8], and result from the synergistic interactions of the system components. The following interaction is common, almost all of them resulting in tangible benefits:

- Beneficial effects of shade and available feeds on livestock;

- Draught animal power for land preparation and crop dung and urine for soil fertility and crop growth;

- Crop residues and agro-industrial by-products (AIBP) from trees in situ;

- Effects of native vegetation on the cost of weed control, crop management and crop growth

-Type of animal production systems (extensive systems combined with arable cropping, and systems integrated with tree cropping) leading to increased income and environmental integrity.

Table 2 indicates the locations of the main tree or perennial crop in many parts of the tropics, and the opportunities for adaptive research, for example sheep and coconuts in the Philippines and the development of sustainable silvopastoral systems. Table 2 also gives an indication of preferred animal options that are appropriate for individual tree crops. Small ruminants appear to be favored in most cases. The fact
Table 2: Potentially important perennial crops and their locations for use in integrated systems in the tropics.

*Small ruminants-Goats and sheep. ** Large ruminants-Buffaloes and cattle

\begin{tabular}{|l|l|l|}
\hline Crop & Location & $\begin{array}{l}\text { Preferred animal } \\
\text { species }\end{array}$ \\
\hline 1. Cashew & S. India, Vietnam & Small ruminants \\
\hline 2. Citrus & $\begin{array}{l}\text { India, Philippines, } \\
\text { Thailand, Vietnam }\end{array}$ & Small ruminants \\
\hline 3. Cocoa & $\begin{array}{l}\text { Malaysia, Papua New Guinea. } \\
\text { Cote de Ivoire, Indonesia, Nigeria }\end{array}$ & Small ruminants \\
\hline 4. Coconuts & $\begin{array}{l}\text { S.China, S.India, Indonesia, } \\
\text { Philippines, SriLanka, Thailand }\end{array}$ & $\begin{array}{l}\text { Large and small } \\
\text { ruminants }\end{array}$ \\
\hline $\begin{array}{l}\text { 5. Fruit trees } \\
\text { e.g; Mango, plantain }\end{array}$ & $\begin{array}{l}\text { N.India, Philippines } \\
\text { Thailand, Costa Rica }\end{array}$ & Small ruminants \\
\hline 6. Oil palm & $\begin{array}{l}\text { China, Indonesia, Malaysia } \\
\text { Papua New Guinea, Thailand } \\
\text { Columbia, Nicaragua }\end{array}$ & $\begin{array}{l}\text { Large small and } \\
\text { small ruminants }\end{array}$ \\
\hline 7. Rubber & $\begin{array}{l}\text { Schema,Indonesia, Philippines, } \\
\text { Malaysia, Thailand, Brazil }\end{array}$ & Small ruminants \\
\hline 8.Teak & Lao PDR, Myanmar & Large ruminants \\
\hline
\end{tabular}

Table 3: Estimated gross margin of profits for meat production using crossbred Katjang goats with varying levels of fertility in Malaysia.

$15 \%$ among kids.

$225 \%$ culling per annum.

${ }^{3} \$ 110$ US per goat weighing about $30 \mathrm{~kg}$.

${ }^{4}$ Cost of cultivated grass is 3.6 US $\$$ cents per $\mathrm{kg}$. fresh weight.

${ }^{5} \mathrm{No}$ costs attached; both components are considered free.

\begin{tabular}{|c|c|c|c|c|c|}
\hline $\begin{array}{l}\text { Fertility level (\% kids weaned/does } \\
\text { mated) }\end{array}$ & 80 & 100 & 120 & 140 & 160 \\
\hline \multicolumn{6}{|l|}{ I. The goat flock } \\
\hline Flock size (breeding does) & 10 & 10 & 10 & 10 & 10 \\
\hline Increase due to kids born & 8 & 10 & 12 & 14 & 16 \\
\hline Less mortality ${ }^{1)}$ & 7 & 8 & 10 & 12 & 14 \\
\hline Net increase in numbers less culls ${ }^{2)}$ & 17 & 18 & 20 & 22 & 24 \\
\hline Cost of goats ${ }^{3)}(\$ \cup S)$ & 1870 & 1980 & 2200 & 2420 & 2440 \\
\hline Cost of cull goats ${ }^{3)}$ (\$ US) & 110 & 220 & 220 & 220 & 220 \\
\hline Less cost of foundation does ${ }^{3)}$ & 1100 & 1100 & 1100 & 1100 & 1110 \\
\hline Total gross revenue per year (\$ US) & 880 & 1100 & 1320 & 1540 & 1760 \\
\hline \multicolumn{6}{|l|}{ II. Cost of production } \\
\hline $\begin{array}{l}\text { (i) On cultivated forages, conc. with } \\
\text { labour }^{4} \text { ) }\end{array}$ & 68.2 & 74.1 & 82.5 & 90.5 & 99.4 \\
\hline $\begin{array}{l}\text { (ii) On uncultivated forages with family } \\
\text { labour }{ }^{5} \text { ) }\end{array}$ & - & - & - & - & \\
\hline
\end{tabular}

Table 4: Effects of climate change on land use and livelihood systems of the poor (26).

\begin{tabular}{|l|l|}
\hline Land use systems & $\begin{array}{l}\text { Livelihood systems of the poor } \\
\text { Including the landless }\end{array}$ \\
\hline - Reduce soil moisture & $\cdot$ Reduced income \\
\hline - Expansion of semi-arid and arid AEZs & $\cdot$ Increased povertys \\
\hline - Increased droughts & $\cdot$ Increased vulnerability \\
\hline - Increased rangelands & $\cdot$ Inability to adapt to heat stress \\
\hline - Woody encroachment & $\cdot$ Increased food and nutritional \\
\hline - Desertification & $\cdot$ Insecurity \\
\hline - Increased overstocking of animals e.g. & - Increased susceptibility to diseases \\
\hline with resultant soil degradation & $\cdot$ Reduced self-reliance \\
\hline - Increase salinization & $\cdot$ Increased urban migration \\
\hline - Reduced biodiversity & \\
\hline - Effects on the systems & \\
\hline - Educed systems services & \\
\hline - Drift out of agriculture & \\
\hline
\end{tabular}

remains that ruminants provide the entry point for the development of integrated tree crops-ruminant systems (Figures 1-4). 
Figure 1: Agroforestry and silvopastoral systems potential and carbon sequestration.

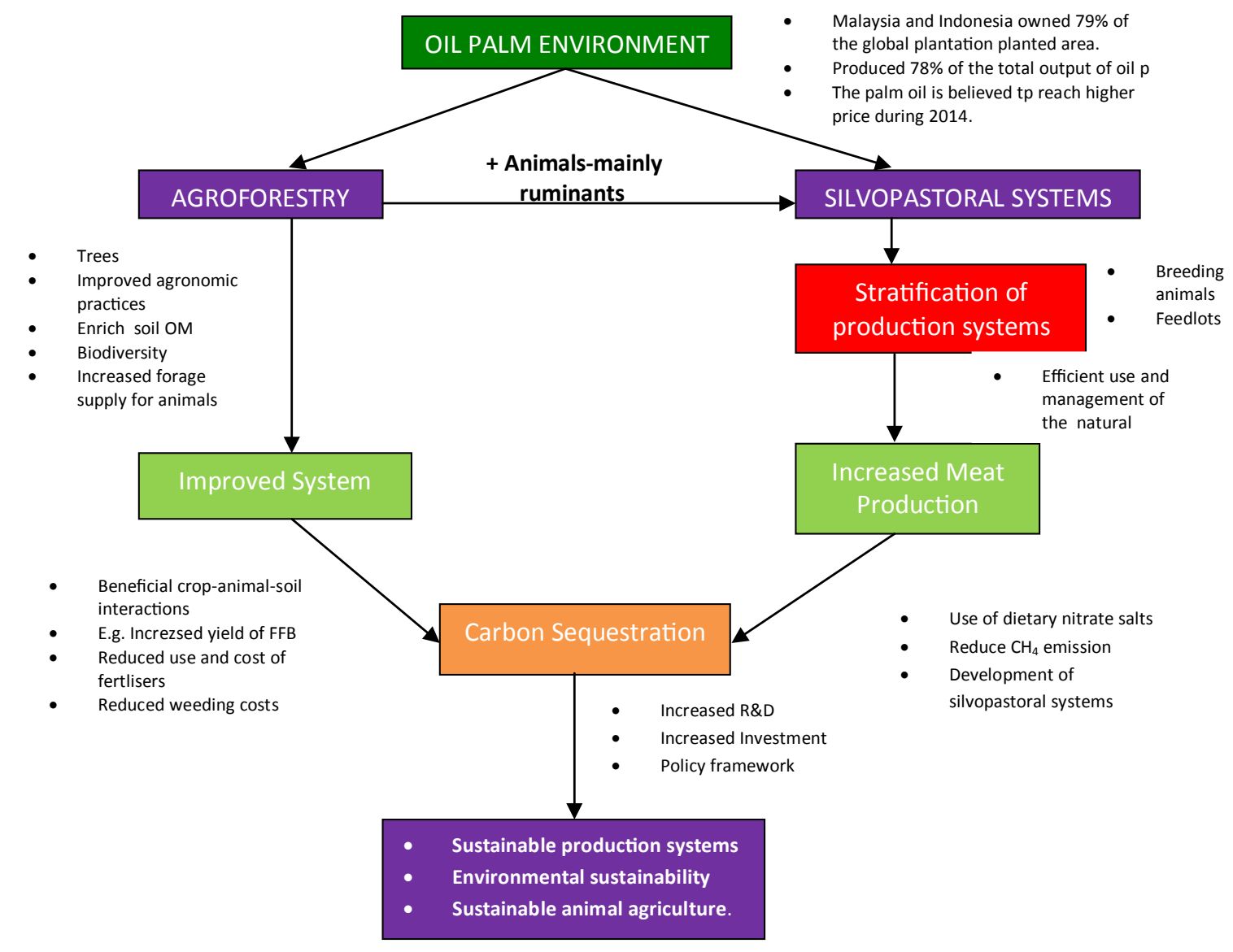

The potential production options are many and are as follows:-

- Breeding ruminants (buffaloes, cattle, goats and sheep) for production systems

Table 2: Potentially important perennial crops and their locations for use in integrated systems in the tropics.

Table 3: Estimated gross margin of profits for meat production using crossbred

Katjang goats with varying levels of fertility in Malaysia.

Table 4: Effects of climate change on land use and livelihood systems of the poor 913).

- Zero-grazing systems (feedlots, goats and sheep)

- Rearing ruminants to use the available oil palm by-products

- Rearing ruminants for grazing and controlling weeds

- Rearing ruminants for draught and haulage operations

- As an entry point for development of integrated NRM and sustainable production systems

- Value addition and total productivity returns and

- As a hedge for possible reductions in the price of crude palm oil.
The oil palm environment offers a number of favorable production to enhance productivity to include:

Forage dry matter availability: $2.99-2.16 \mathrm{mt} / \mathrm{ha}$ for three- and five-year-old palms, reducing to $435-628 \mathrm{~kg} / \mathrm{ha}$ for $10-29$ year-old palms [9]

60-70 forage species among young palms, which are reduced by about $66 \%$ among older palms [10]

$>$ Forage categories: grasses, dicotyledons, legumes and ferns of $60,2,11$ and $17 \%$ for $3-10$ year old palms and $50 \%$ for grasses, $13 \%$ for dicotyledons. $2 \%$ for legumes and 35\% for ferns in over 10 year trees

$>2$ and 35\% for 3-5-year-old, 6-10-year-old and over 10-year-old palms respectively [11] about $72-93 \%$ of the forages are palatable and of value to ruminants.

$>$ Indigenous Kedah-Kelantan and Bali cattle are well suited to integration with oil palm

Carrying capacity: 3 steers/ha in 3-4-year-old palms, with average daily gain of about $260-320 \mathrm{~g} /$ day.

The strategy of stratification within silvopastoral systems enables the development of other production systems including specialization and intensification. Breeding animals to meet the needs of zero grazing system is one example. Likewise there could be a separate production 
Figure 2: Brahman and Hereford cattle integrated with oil palm in Sabah, Peninsular Malaysia.

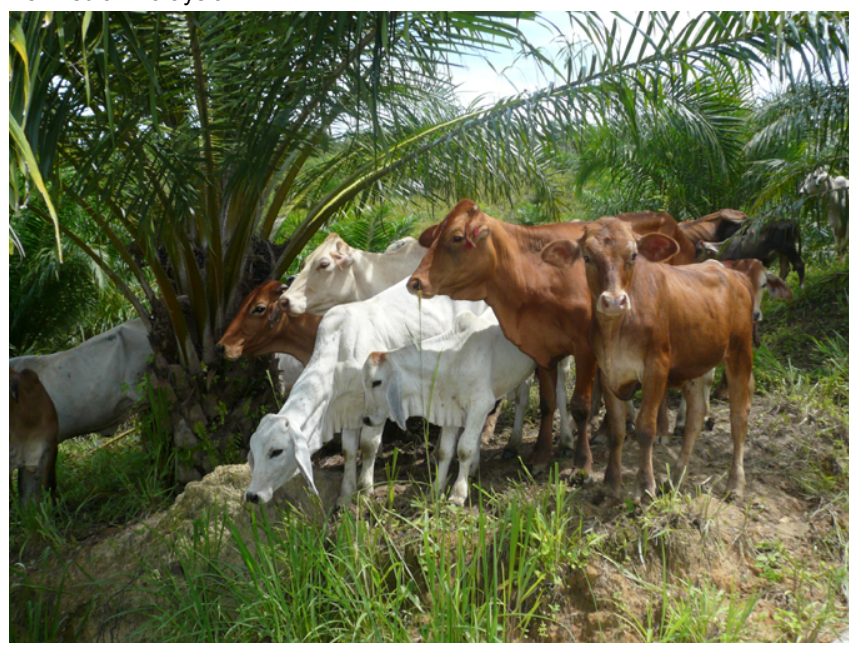

Figure 3: Goats integrated with oil palm and seeking shelter under banana trees in Perak in Malaysia.

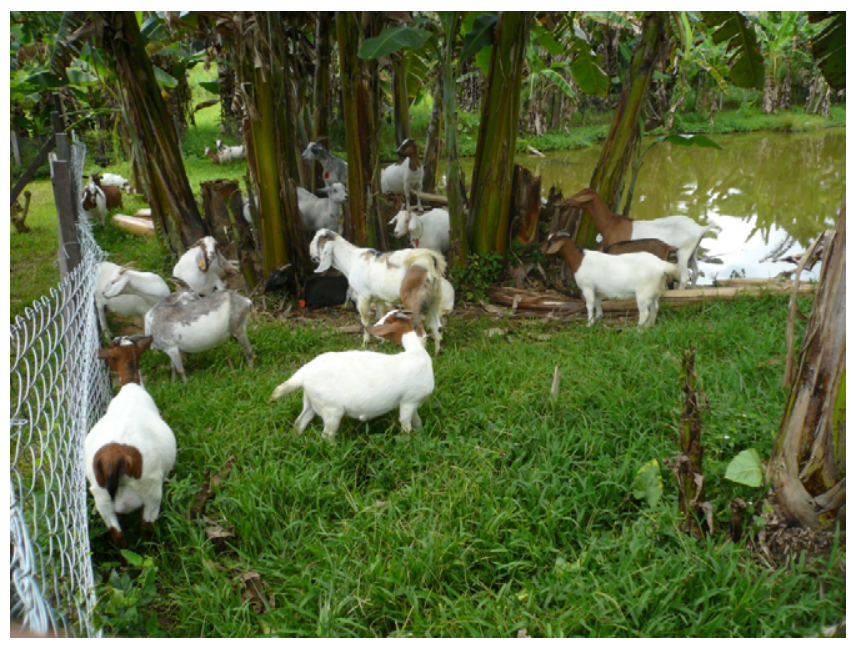

system for goats. The diversified operations also enable the development of sustainable production systems as well as carbon sequestration in the long term.

\section{Economic Impacts}

\section{South Asia, South East Asia and the Pacific Islands}

There exist 26 case studies which provide convincing information on economic impacts of the systems involving cattle. The review gave the following key results [12].

Increased animal production and income: This arises from increased productivity and meat off takes

Increased yield of FFB and income: By about $30 \%$ with measures of between 0.49-3.52 tones/ha/yr.

Savings in weeding costs: By about $47-60 \%$, equivalent to $21-62$ $\mathrm{RM} / \mathrm{ha} / \mathrm{yr}$

Internal rate of return: The IRR of cattle under integration was $19 \%$ based on actual field data.
Figure 4: Typical photograph of sheep integrated with coconuts in the Laguna area, Philippines.

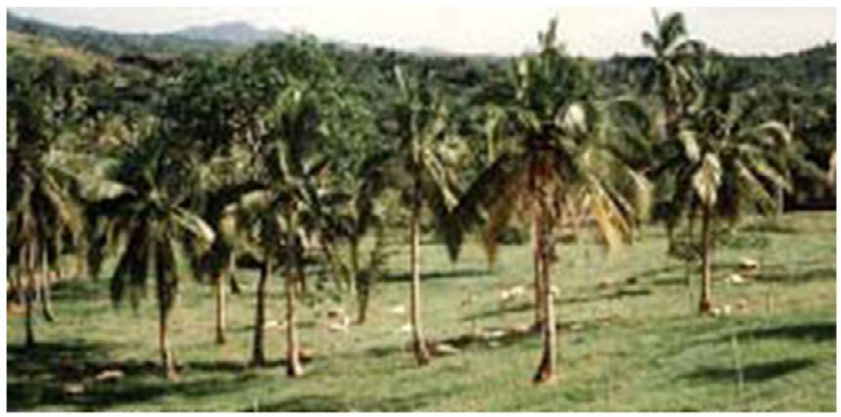

Several theoretical calculations approximate to this value.

\section{Integrated goats-oil palm production system in Malaysia}

The concept of promoting the benefits of integrated systems presents an alternative model here which highlights the role of goats and the potential economic benefits of their integration specifically with the oil palm. There benefits are associated with are two main attributes:-

- The ability of the goat to digest fibrous feeds, and especially coarse roughages efficiently and use to advantage the mixed forage biomass of which $72-93 \%$ are suitable to feed ruminants [13] in oil palm plantations. In other words the non-competitive use of the forage biomass with a variety of feeds and the resultant advantages is a remarkable low input system of goat production which is associated with high profit margins. The available forage biomass under oil palm can be more fully utilized if mixed grazing is involved, such as goats and cattle

- The versatile ability of the goat to convert the forage biomass to precious meat, milk and skins together with the beneficial advantages to the oil palms, gives economic margins that are quite significant.

Goats are versatile animals with an ability to convert the forage biomass to precious meat, milk and skins that Goat meat fetches the highest prices among all meats in the open market. These attributes, together with the beneficial advantages to the oil palms, provide significant economic margins. Table 3 gives data and calculations on the scale and extent of the monetary gains, keeping in mind that goat meat fetches the highest prices among all meats in the open market. In this context, an important management issue influencing productivity and income generation from goats, concerns their fertility and the productive lifespan. The higher fertility implies more number of kids born. Calculations on the importance of good management influencing fertility and productivity on the scale, impact and income generation clearly showed that over for a 10-doe unit over seven years of productive life, with varying fertility levels of between $80-160 \%$.(\% kids weaned/does mated) gave a total gross revenue of between US $\$ 860-1760$ per year.

\section{West Africa}

Coconuts, oil palm, cocoa and fruit trees are very common throughout West Africa, but R and D to integrate the animal component into some of these have been very weak, due probably to priorities and lack of resources.

The value of alley farming combining maize and supplemented with Leucaena or Gliricidia forages fed to livestock have been shown to be economically beneficial. West African djallonke sheep and West 
African dwarf goats increased live weight. Continuous alley farming was more profitable than alley farnmig with fallow, or conventional no-tree farming [14].

\section{Latin America and the Caribbean}

Silvopastoral systems are part of traditional farming systems throughout Latin America and the Caribbean for the benefits, including sustainability, which have been previously highlighted. They are especially common in farms engaged in cattle production. In Columbia it has been found that trees were grown in $26-69 \%$ of the farms in which there was diversification with the plating of larger trees gave more shade and also produced timber [15].

In Costa Rica the profitability of milk production in small farms was higher when high value trees were planted than those without trees, especially when labor costs increased. Cashew and other high value timber trees have also been used in the development of silvopastoral systems [16].

\section{Climate Change: Carbon Sequestration and Greenhouse Gases}

A discussion on silvopastoral systems is incomplete without a reference to carbon sequestration and greenhouse gases. The first point to make is that it is an area with a paucity of $\mathrm{R}$ and $\mathrm{D}$ an needs urgent attention It is defined as the complex and secure storage of carbon that would otherwise be emitted or remain in the atmosphere [17]. The expanding land areas under oil palm provide good opportunities for carbon sequestration through more widespread use of grasses and tree legumes, and improved forage management practices, with resultant decreased carbon atmospheric emissions and global warming. It has been calculated [18] that in mixed farming systems, the carbon sequestered per hectare was $0.32 \mathrm{tc} / \mathrm{ha} / \mathrm{yr}$. The practical implication of this is that agronomic practices need to enhance these carbon sinks through enrichment of soil organic matter and the forage biomass under the oil palm.

Associated with above is the issue of greenhouse gas emissions (GHG), mainly $\mathrm{CH}_{4}, \mathrm{~N}_{2} \mathrm{O}$ and $\mathrm{CO}_{2}$ and their effects on climate change or global warming. Improved grass-legume pastures to feed grazing ruminants will have the beneficial effect of enhancing carbon sequestration and releasing more $\mathrm{O}_{2}$ into the atmosphere. On the other hand, the presence of grazing ruminants will mean emissions of more $\mathrm{CH}_{4}$ into the atmosphere, and their possible effects. In Brazil, Zebu cattle grazing tropical pastures produced a larger methane loss of 27 $\mathrm{g} / \mathrm{kg}$ compared to either Holstein or Nellore cattle fed sorghum silageconcentrate diets that averaged $22 \mathrm{~g} / \mathrm{kg}$. Holstein or Nellore cattle on Brach aria or Panicum pastures consuming sorghum had methane losses that were close to the temperate forage-based diet of $20 \mathrm{~g} / \mathrm{kg}$ [19].

Mitigation and adaptation are important aspects of ways to cope with climate change. Strategies to reduce GHG have largely focused on methanogen inhibitors and substrate levels, rather than at the feed quantity and quality end In practice, strategies will need to be developed that can have a balance between the two types of emissions which is consistent with minimal effects on climate change. Recent studies suggest that the fermentable nitrogen requirements of ruminants on diets based on low protein cellulosic materials can be met from nitrate salts $\{18\}$ and this potentially reduces methane production to minimal levels $[20,21]$ demonstrated that with adaptation, young goats given a diet of straw, tree foliage and molasses grew faster with nitrate as the fermentable $\mathrm{N}$ source by comparison [22] have shown a $60 \%$ reduction in methane production by sheep fed nitrate in a corn silage based diet.
They have shown persistent reduction of $16 \%$ methane in dairy cows supplemented with nitrate [23] quoted by Hulshof et al. [24] and a 32\% reduction in methane production in beef cattle in Brazil when 2.2\% nitrate replaced urea in a sugarcane/concentrate.

The Asian Development Bank [25] has produced a regional study on South East Asia on the economics of climate change highlighting perspectives on the regional interdependencies of climate change impacts and policies, and pooling of resources to address shared challenges with reference to Indonesia, Philippines, Thailand and Vietnam. The study has indicated that the agricultural dependent economies will contract by as much as $6.7 \%$ annually. The economic cost according to the report would be $2.2 \%$ of GDP by 2010 if only the impact on markets is considered, $5.7 \%$ if health costs and biodiversity losses are factored in, and $6.7 \%$ if losses from climate-related disasters are also included. The latter far exceeds the projected cost globally of climate change, estimated at $2.6 \%$ of GDP each year to the end of the century. Table 4 gives summary of the Effects of climate change on land use and livelihood systems of the poor.

\section{Policy Framework}

The task of stimulating waning agriculture, encouraging growth and promoting silvopastoral system to enhance productivity, food security and a clean environment provides major challenges for $\mathrm{R}$ and D. These need to be supported by strong policy requirements and are reflected in the following:-

- Affirmation of official policy to address waning agriculture $[26,27]$, its revitalization efficiency in integrated NRM [28], and intensification of production systems (29)

\section{- Priority for food insecurity and increased self-reliance}

- Priority for concerted R and D on rain fed agriculture and small farm systems that are progressive and can intensify [30].

- Priority for pro-poor community-based activities that adapt to climate change.

- Promotion of ways and means to enhance $\mathrm{C}$ sequestration and reduce emissions of GHG in silvopastoral systems.

- Integrated tree crops-ruminant systems are underestimated. Policy interventions are required to stimulate their development.

- Empowerment of women is central to enhance their effective contribution to the use of productive resources for food and nutritional security, and the stability of farm households [30].

- Building systems $\mathrm{R}$ and $\mathrm{D}$ capacity to deal with complex problems of crop-animal-soil-water interactions and effects of climate change.

- Micro-credits should be made more accessible to small farms and the landless.

- Improvements are necessary for rural-urban market linkages, collection and processing centers to reduce transaction costs and in the value chain.

- Increase investments and promote public-private sector partnerships for greater engagement and agricultural productivity.

\section{Investing in Animal Agriculture}

Increased investments are justified and urgently needed to develop the LFUs, in view of the potential impact on increased productivity, poverty and food security, improved livelihoods and the environment. 
It is especially important to note that in studies in India [31] and China [32] the returns to investments are very much higher in these areas in comparison to areas that have benefited from the Green Revolution. In the Indian context, improving agrarian prosperity and rural development focusing on the five pillars of public investment, credit, infrastructure (roads, transport and agro-processing), stable markets and knowledge transformation of farmers have been proposed [33]. Similarly, it has been reported that the estimated returns to agricultural $\mathrm{R}$ and $\mathrm{D}$ are high, and high enough to justify an even greater investment of public funds [34] as was reflected in the investments and policies on the use of high-yielding rice varieties that resulted in the success of the Green Revolution in India.

\section{Adoption of Silvopastoral Systems}

Overall and across regions, $\mathrm{R}$ and $\mathrm{D}$ on the development of this system has been very meagre. For a variety of reasons, the adoption rates of the system and methodologies continue to be very low. Adoptions for integrating ruminants with in general, and cattle and goats with oil palm are not surprising, and can make a very poor contribution to production household requirements.

Given the very low adoption of integrating ruminants with oil palm for example, it is relevant to enquire into the reasons for this situation. There are many reasons for this, and these are enumerated below:-

- Poor awareness of the potential of integration and the benefits and value addition of silvopastoral systems e.g. oil palm and ruminants.

- Associated with above, is the strong resistance by the croporiented plantation sector, and are least interested in introducing animals to the system.

- Crop scientists and plantation managers all have a plant production background without any interest in animals

- This perception is also fuelled by high prices for the key commodities e.g. palm oil.

- Additionally, they are also not interested in making more capital investments e.g. fencing and fodder production.

- Inadequate technology application and week understanding of systems $\mathrm{R}$ and $\mathrm{D}$.

- Unattractive investment climate.

- Shortage of estate workers

- Onset of climate change and reservations about the effects on the tree crop, and

- Absence of policies to encourage integrated systems.

\section{Ruminants as the Entry for Development}

The investments will also be enhanced by increased emphasis on the integration of ruminants in these AEZs. Ruminants are an integral part of the LFUs such as the presence of goats, sheep and camels. The wider and more intensive use of ruminants in these areas including in silvopastoral systems is reflected in such advantages in them such as non-competitive use of mixed forage biomass, improved cycling of soil nutrients, improved soil fertility and conservation of soil and water, enables increased productivity, increased ecological and economic efficiency, and encourages wider replication and development of the system. It is suggested that ruminants are the entry point for development of these areas in a manner that is consistent with the efficiency of NRM, and preservation of the agricultural landscape.
Figure 1 captures these aspects in tandem with the targets that are clearly important.

Climate change will take effect irrespective of predictable difficulties and the consequences. Two major possibilities are of grave concern: firstly that of reduced arable land for food production for humans and reduced grazing areas for ruminants. Secondly and more importantly, the climatic effects can push back several more million people along with the million resource-poor people who already live there, to become more vulnerable and poorer $(26,35)$ r. While $\mathrm{R}$ and $\mathrm{D}$ can provide mitigation and adaptive methodologies and solutions, for the vulnerable people who live there, time is not in their hands. The priority for the application of innovative improved technologies is urgent,to remove current constraints in the immediate tomorrow. Both these concerns need to be reinforced by strong policies. The enduring hope is secure and sustained food supplies, decreased poverty, significantly improved livelihoods, sustainable animal agriculture, and an intact agricultural landscape that will be cherished by future generations [35].

\section{Conclusions}

Climate change will take effect irrespective of predictable difficulties of the consequences. Two major consequences are of grave concern: firstly that of reduced arable land for food production for humans and reduced grazing areas for ruminants. Secondly and more importantly, the climatic effects can push back several more million people along with the million resource-poor people who already live there to become more vulnerable and poorer. While $\mathrm{R}$ and $\mathrm{D}$ can provide mitigation and adaptive methodologies and solutions, for these, time is not in their hands. The priority for the application of innovative improved technologies is urgent to remove current constraints in the immediate tomorrow. These need a strong policy framework to support maximum food production and respond to the needs and satisfaction of consumer preferences.

The complexities of the environment, externalities, and the threats of climate change, these present major challenges for $\mathrm{R}$ and $\mathrm{D}$ that cannot be ignored, Their resolution is our collective responsibility and a moral obligation. A definition of clear priorities and pathways for predictable solutions provide many reasons for the development of, increased contribution from animal agriculture, viewed from the perspective of production to consumption systems. The rain-fed areas including silvopastoral systems, currently very underestimated, provide compelling and urgent opportunities in the presence of several million landless and very poor vulnerable people. Also, the relatively large populations of ruminants therein can serve as the entry point for development. Improved efficiency of NRM, concerted application of yield-inducing technologies, and ways of mitigating and adapting technologies to cope with the effects of climate changes which can significantly enhance the capacity of food production. Social and effective development policies are also needed to spur sustainable increased agricultural productivity, improved human welfare, and self- reliance in the future. The hope for small farm systems, the very poor and the landless is that they will be more secure and can produce sustained food supplies, with the full knowledge that sustainable animal- agriculture can demonstrate its full potential, to realize the objectives of poverty, hunger and environmental degradation.

\section{References}

1. Devendra C (2012) Intensification of Integrated Natural Resources Use and Agricultural Systems in the Developing World. Agrotechnol 1: e101.

2. FAO (Food and Agriculture Organisation) (1996) FAO AGROSTAT 1995, 49 , FAO, Rome, Italy. 
3. Devendra C, Sevilla C, Pezo D (2001) Food-feed systems in Asia. Asian Australasian Journal of Animal Science 14: 733-745.

4. Carangal VR, Sevilla C (1993) Crop-animal systems research in Asia Proceedings V11th World Conference on Animal Production. Edmonton, Canada: 367-386.

5. ESCAP (2008) Economic and social survey of Asia and the Pacific 2008. Sustaining growth and sharing prosperity. Bangkok, Thailand.

6. CGIAR/TAC (2000) (Consultative Group on International Agricultural Research/ Technical Advisory Committee) CGIAR priorities for marginal lands, CGIAR, Washington, USA.

7. Devendra C, Thomas D (2002) Crop-animal interactions in mixed farming systems in Asia. Agricultural Systems 7: 27-40.

8. David J. Griggs, Maria Noguer (2001) Climate change 2001: The scientific basis. Contribution of Working. Group I to the Third Assessment Report of the Intergovernmental Panel on Climate Change Climate change. Weather 57: 1-3.

9. Current $D$, Scherr $S$ (1996) Farmer costs and benefits from agroforestry and farm Forestry projects in Central America and the Caribbean. Agroforestry Systems 30: 87-10

10. Devendra C, Shanmugavelu S, Wong H K (2007) Integrated tree-crops ruminant systems: expanding the research and development frontiers in the oil palm. In: Proceedings Workshop on Integrated tree crops-ruminant systems (ITCRS/Assessment of status and opportunities in Malaysia. Academy of Science Malaysia 1-23.

11. Chen CP, Wong HK, Dahalan I (1993) Herbivors and the plantations, Proceedings. Third International Symposium on the Nutrition of Herbivores (Ed. Ho,Y.W) Penang, Malaysia 71-81

12. Wong CC, Chin FY (1998) Meeting nutritional requirement of cattle from natural forages in oil palm plantation. Paper presented at National Seminar on Livestock and Crop Integration in Oil Palm, Kluang, Johor.

13. Devendra C (2007) Goats: biology, production and development in Asia Academy of Sciences Malaysia, Kuala Lumpur, Malaysia.

14. Reynolds SG (1995) Pastures and Cattle under Coconuts. FAO Plant production and Protection paper No.91, 33.

15. Cajas-Giron YS, Sinclair (2001) Cultivation of multistorey silvopastoral systems on seasonality on dry pastures in the Caribbean region, Agroforestry systems 53: 215-225.

16. Lascano GF, Pezo DA (1994) Agrofoestry systems in humid forest margins of tropical America from a livestock perpective. In Copland, J/W, Djajanegara. A. And M.Sabrani (Eds) Agroforestry for human welfare, ACIAR Proceedings No 55, Canberra, Australia 17-24

17. Watson RI, Noble IR, Ravindranath B, Verado DJ, Dokken DJ (2000) Intergovernmental Panel on Climate Change (IPCC), Special report on land use change and forestry, IPCC Secretariat, Geneva, Switzerland (Mimeograph).

18. Pretty JN, Noble AD, Bossio D, Dixon J, Hine RE, et al. (2006) Resourceconserving agriculture increases yields in developing countries. Environ Sci Technol 40: 1114-1119

19. Lima MA, Primavasi O, Dermachi JJ, Manella M, Frighetto RT (2004) Inventory improvements for methane emissions from ruminants in Brazil, Rpt. to the Environment Protection Agency (EPA), USA.

20. Trinh PH, Ho QD, Preston TR, Leng RA (2009) Nitrate as a fermentable nitrogen supplement for goats fed forage based diets low in true protein. Livestock Research for Rural Development 21.
21. Leng RA (2008) The potential of feeding nitrate to reduce enteric methane production in ruminants. A Report to the Department of Climate Change. Common wealth Government of Australia. Canberra, ACT. Australia.

22. van Zijderveld SM, Gerrits WJ, Apajalahti JA, Newbold JR, Dijkstra J, et al. (2010) Nitrate and sulfate: Effective alternative hydrogen sinks for mitigation of ruminal methane production in sheep. J Dairy Sci 93: 5856-5866.

23. Zijderveld SM van, Dijkstra J, Gerrits WJJ, Newbold JR, Perdok HB (2010) Dietary nitrate persistently reduces enteric methane production in lactating dairy cows.In :greenhouse gases and animal agriculture conference October 3-8, 2010 Bamff, Canada.

24. Hulshof RB, Berndt A, Gerrits WJ, Dijkstra J, van Zijderveld SM, et al. (2012) Dietary nitrate supplementation reduces methane emission in beef cattle fed sugarcane-based diets. J Anim Sci 90: 2317-2323.

25. Asian Development Bank (2009) The economics of climate change in South East Asia: a regional review. Asian Development Bank, Manila, Philippines 91.

26. Devendra C (2010) Small farms in Asia. Revitalizing agricultural production food security and rural prosperity. Academy of Sciences Malaysia, Kuala Lumpur, Malaysia.

27. Devendra C (2004) Integrated tree crops-ruminants systems. The potentia importance of the oil palm. Outlook on Agriculture 33: 157-166

28. Devendra C (2007) Perspectives on animal production systems in Asia. Livestock Science 106: 1-18.

29. Devendra C (2009) Intensification of integrated oil palm-ruminant systems: enhancing increased productivity and sustainability in South East Asia. Outlook on Agriculture 38: 71-82.

30. Devendra C, Gender equity in sustainable animal-agriculture: enhancing empowerment and the contribution of women for improved livelihoods, stable households and rural growth. Second. $2^{\text {nd }}$ Asian-Australasian Dairy Goat Conference, Bogor, Indonesia (Extended Abstr).

31. Fan S, Hazell P, Thorat $H$ (2000) Targeting public investments by agro ecological zone to achieve growth and poverty alleviation goals in rural India. Food Policy 20: 411-428.

32. Fan S, Zhang L, Zhang X (2000) Growth and poverty in rural China: The role of public investments. Environment and Production Technology Division Discussion Paper No.66, International Food Policy Research Institute, Washington DC, USA.

33. Shankar R, Maraty P (2009) Concerns of India's farmers. Outlook on Agriculture, 38: 96-100

34. Pardey PG, Beintema NM (2001) Slow magic-Agricultural R and D: a century after Mendel, International Food Policy Research Institute Food Policy Report, Washington DC, USA.

35. Devendra C, Chantalakhana C (2002) Animals, poor people and food insecurity: opportunities for improved livelihoods through natural resource management. Outlook on Agriculture 31: 161-176. 